\title{
Clitoromegaly caused by ovarian stimulation in a preterm newborn: ovarian hyperstimulation syndrome of preterm babies
}

\author{
Elvan Bayramoğlu ${ }^{1 \oplus}$, Şenay Savaş Erdeve ${ }^{1 \oplus}$, Betül Emine Derinkuyu ${ }^{2 \oplus,}$ \\ İstemi Han Çelik ${ }^{3 \oplus}$, Semra Çetinkaya ${ }^{1 \oplus}$, Zehra Aycan ${ }^{1 \oplus}$ \\ Clinics of ${ }^{1}$ Pediatric Endocrinology and ${ }^{2}$ Radiology, University of Health Sciences, Dr. Sami Ulus Obstetrics and Gynecology and \\ Pediatrics Training and Research Hospital, Ankara; ${ }^{3}$ Clinic of Neonatology, University of Health Sciences, Etlik Zubeyde Hanim \\ Women's Health Teaching and Research Hospital, Ankara, Turkey.
}

\begin{abstract}
Background. Preterm ovarian hyperstimulation syndrome (POHS) is an uncommon disorder characterized by prematurity, hypogastric and upper leg swelling, high serum estradiol and gonadotropin levels, and ovarian cysts. Immaturity of the gonadal axis is accepted as the cause. But still, other etiological factors are suspected.

Case. A preterm baby who was born at 24 gestational weeks was referred to our clinic for ambiguous genitalia on day 118 of life. Labia majora and clitoris was edematous. Clitoris length was $1.5 \mathrm{~cm}$. On laboratory evaluation: 17OH-Progesterone: $1.84 \mathrm{ng} / \mathrm{ml}$, dehydroepiandrosterone sulphate (DHEA-S): $139 \mu \mathrm{g} / \mathrm{dl}$, total testosterone (T.T): 88 ng/dl, luteinizing hormone (LH): 22.5 mIU/l, Follicle stimulating hormone (FSH): 15.7 mIU/1, estradiol $\left(\mathrm{E}_{2}\right): 447 \mathrm{pg} / \mathrm{ml}$. Karyotype analysis was $46, \mathrm{XX}$. There was a $25 \times 14 \times 12 \mathrm{~mm}$ ovarian cyst detected on ultrasound. On follow-up, $E_{2}$ levels and cyst size increased, and there was $4 \mathrm{~mm}$ pericardial effusion on echocardiography at the time.
\end{abstract}

Conclusion. In this paper, we present a case with POHS and to discuss possible pathophysiological mechanisms and treatment. This is the first case of POHS developing pericardial effusion.

Key words: preterm ovarian hyperstimulation syndrome, clitoromegaly, ovarian cyst, pericardial effusion.

Ovarian hyperstimulation syndrome of preterm babies (POHS) is a rare syndrome of preterm girls characterized by tissue edema especially in hypogastric and vulvar areas and upper leg, high levels of gonadotropic hormones and presence of ovarian cysts. Preterm birth causes insufficient negative feedback mechanism due to the immaturity of hypothalamic-pituitarygonadal (HPG) axis and early disappearance of placental sex steroids. Therefore, this situation has been held responsible for the pathogenesis of syndrome. ${ }^{1}$ Still, other etiological factors are suspected because not all preterm babies

$凶$ Elvan Bayramoğlu

elvanbayramoglu@gmail.com

Received 29th February 2020, revised 30th May 2020, accepted 9th June 2020. suffer from the syndrome. It must be kept in mind in the differential diagnosis of ambiguous genitalia.

Here we present the case and clinical presentation of a preterm infant who was referred for ambiguous genitalia and diagnosed with POHS in order compare with the data in literature and discuss the pathogenetic mechanisms.

\section{Case Report}

A preterm baby who was born at twenty fourth gestational week with 770 grams birth weight, was referred to our outpatient clinic to be evaluated for ambiguous genitalia on day 118 of life $\left(40^{+5} \mathrm{GW}\right)$. History revealed that it was a preterm birth because of fetal distress, the 
mother had betamethasone treatment in the prenatal period; the baby had been admitted to the neonatal intensive care unit (NICU) for prematurity, respiratory distress syndrome and apnea for 117 days and was on mechanical ventilator for 40 days. On 35th day of NICU stay (29 GW), detecting body edema localized in hypogastric area, upper legs, labia majora and clitoris, laboratory tests were performed for total protein, albumin, urea, creatinine and electrolytes which were normal and there was no cardiac pathology on echocardiography. In spite of decreased edema in hypogastric area and upper legs, she was referred for persistent clitoromegaly. On presentation, labia majora and clitoris were edematous. Clitoris length was $1.5 \mathrm{~cm}$ (upper limit of clitoral length for $40 \mathrm{GW}$ is $6 \mathrm{~mm}$ ) (Fig. 1A). ${ }^{2}$ There were two urogenital orifices and there were no gonads palpation. Thelarche was tanner stage 2, pubarche was 1. On laboratory evaluation, ACTH: $24 \mathrm{pg} / \mathrm{ml}$
(1-46 pg/ml), 17OH-Progesterone: $1.84 \mathrm{ng} / \mathrm{ml}$ (0.53-1.86 ng/ml), DHEA-S: $1393 \mu \mathrm{g} / \mathrm{dl}(1-45 \mu \mathrm{g} /$ $\mathrm{dl})$, Androstenedione (AS): $1.8 \mathrm{ng} / \mathrm{ml}(0.18-0.80$ $\mathrm{ng} / \mathrm{ml})$, total testosterone (T.T): $88 \mathrm{ng} / \mathrm{dl}$ (0-40 ng/dl) , LH: $22.5 \mathrm{mIU} / \mathrm{l}(0.02-7.0 \mathrm{mIU} / \mathrm{l}), \mathrm{FSH}$ : $15.7 \mathrm{mIU} / \mathrm{l}(0.24-14.2 \mathrm{mIU} / \mathrm{l}), \mathrm{E}_{2}: 447 \mathrm{pg} / \mathrm{ml}(0-$ $36 \mathrm{pg} / \mathrm{ml})$. Karyotype was $45, \mathrm{XX}$. There was a $25 \times 14 \times 12 \mathrm{~mm}$ multilocular cyst in right ovary detected on ultrasound (Fig. 1B). The patient was reevaluated frequently at the clinic with laboratory tests and ultrasound, and wasn't started on any medication since the diagnosis was PHOS was suspected. On postnatal day $128, \mathrm{E}_{2}$ levels were increased as well as the size of the cyst in the ovary, endometrium was measured $3 \mathrm{~mm}$. There was $4 \mathrm{~mm}$ pericardial effusion on echocardiography at the time. The patient was seen more frequently then, due to risk of ovarian torsion and rupture of the cyst. On day 165 of life, $E_{2}$ levels and the size of the ovarian cyst decreased significantly. At
A.

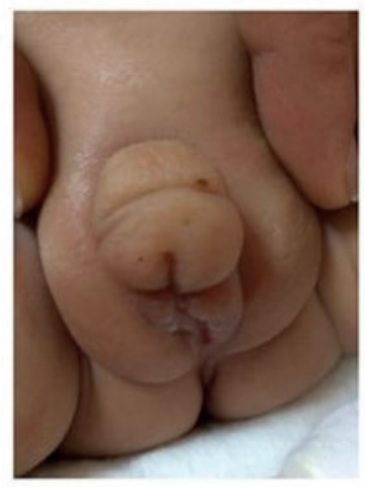

at the time of presentation Day $118\left(40^{45} \mathrm{GW}\right)$

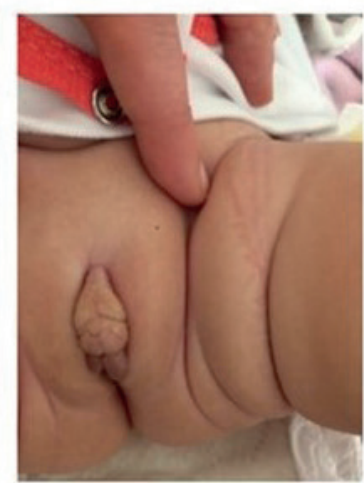

5,5 months

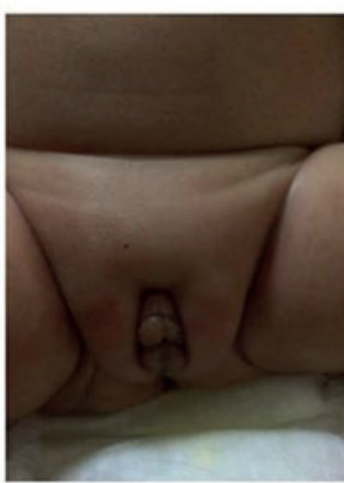

8 months

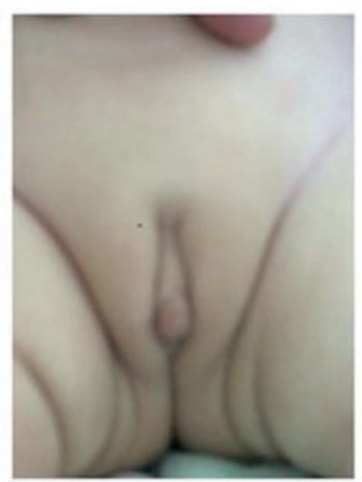

12 months

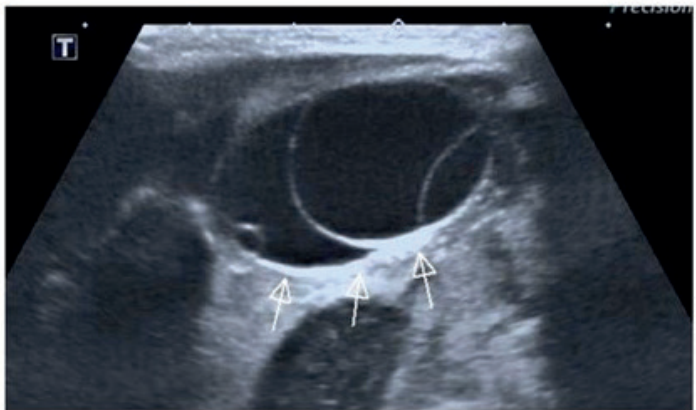

B.

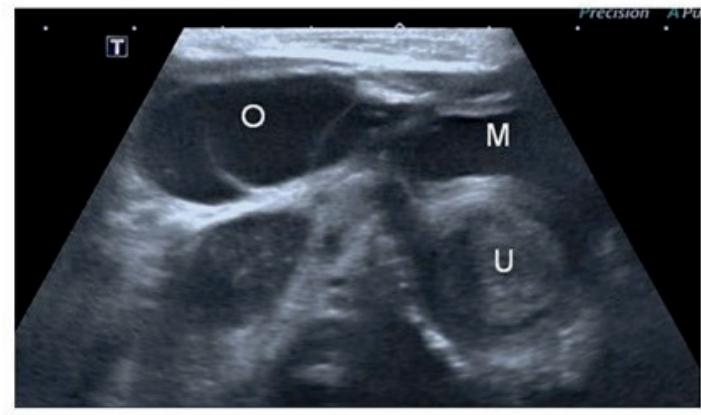

Fig. 1A. Physical examination- external genitalya, B. Giant ovarian cyst in pelvic USG seen at 5 months (the arrows point to the cysts). 
8 months of age, physical examination was normal, gonadotropin levels were decreased and the ovarian cyst disappeared (Fig. 1A, 1B). On her last visit at the age of 1 , bone age was 15 months. Echocardiography was normal with no pericardial effusion. Laboratory and ultrasound findings of the patient are given in Table I. Informed consent was obtained from the parents.

\section{Discussion}

The activation period of the HPG axis in the first months of life is thought to have an important role on development of gonads and reproductive function. This axis can be suppressed by the low levels of sex steroids in term babies and moderate increases in $\mathrm{E}_{2}$ levels can be observed.,4 On the other hand, in preterm babies, immaturity of HPG axis and sudden decrease in levels of placental sex steroid results in disrupted negative feedback mechanism, increased gonadotropin levels, ovarian hyperstimulation causing cysts and very high levels of $\mathrm{E}_{2}$ which altogether result in POHS. ${ }^{5}$ Since it is not seen in all preterm babies, it is postulated that other mechanisms play a role in POHS pathogenesis. In ovarian hyperstimulation syndrome (OHSS) seen in adult females and characterized by ovarian follicular cysts, generalized edema and increased levels of gonadotropins and $\mathrm{E}_{2}$; three mechanisms are held responsible: gestational spontaneous OHSS which is the result of increased placental production of endogenous hCG, iatrogenic OHSS caused as a complication of drugs used for in vitro fertilization and OHSS caused by increased hCG/LH sensitivity because of FSH receptor mutation. ${ }^{6}$ All of the three situations are the result of very high levels of hCG/LH or increased sensitivity of hCG/LH with stimulation of FSH receptors. Hence it is thought that variable levels of LH can be an important factor for development of edema in POHS. ${ }^{1,6}$ Since the development and resolving of edema and ovarian cysts occur at the same time in POHS, vascular endothelial growth factor secreted from theca and granulosa cells, is thought to have a role in edema. ${ }^{7}$ But ovarian cysts are not specific for POHS. In $30-34 \%$ of healthy newborn babies / fetuses, single or multiple ovarian cysts can be found. ${ }^{1}$ There is also a report of a POHS case without a functional ovarian cyst. ${ }^{6}$ Starzky et al. ${ }^{1}$ in an evaluation of 9 cases of POHS, showed there is no correlation of disease severity and levels of $\mathrm{E}_{2}$ as in OHSS. In our patient, decreased levels of $\mathrm{E}_{2}$ was accompanied by regression of clinical symptoms. This lack of uniform correlation between disease severity and $\mathrm{E}_{2}$ levels can result from the difference of sensitivity of peripheral $\mathrm{E}_{2}$ receptors among patients.

Severe complications such as ascites, acute renal failure, hypovolemic shock, pleural and pericardial effusion caused by capillary leak syndrome in OHSS are not defined in POHS cases and this can be the result of decreased peripheral $\mathrm{E}_{2}$ receptor sensitivity. To the best of our knowledge, this is the first case of pericardial effusion in POHS. Minimal pericardial effusion detected in the period when $E_{2}$ levels were highest, was absent in the control echocardiography when $\mathrm{E}_{2}$ levels were normal. Clinical presentation of severe OHSS in adults has been reported as the development of pleural effusion and, much less frequently, pericardial effusion. ${ }^{8,9}$ In a Belgian multicenter study, Delvigne indicated that in 128 patients, there was 3\% incidence of pericardial effusion in OHSS. Development of pericardial effusion with cardiac tamponade is a very rare but life-threatening complication in OHSS. ${ }^{9}$ The pathogenetic chain of OHSS has not been clarified completely. OHSS is associated with an activation of renal and ovarian angiotensin systems and a release of vasoactive substances, such as vascular endothelial growth factor (VEGF) and interleukins 1, 2, and 6, which modify the permeability of the vascular beds. ${ }^{70-12}$ An important role is probably played by tumor necrosis factor or estrogenes. ${ }^{13,14}$ The minimal pericardial effusion detected when $\mathrm{E}_{2}$ level was highest in our patient, disappeared when the $\mathrm{E}_{2}$ level returned to normal. This supports the possible role of $E_{2}$ in the pathophysiology. No symptoms of estrogen 
Table I. Clinical and laboratory parameters at presentation and on follow up.

\begin{tabular}{|c|c|c|c|c|c|c|c|}
\hline & $\begin{array}{l}\text { Day } 35 \\
(29 G W)\end{array}$ & $\begin{array}{l}\text { Day } 118 \\
\left(40^{+5} \mathrm{GW}\right)\end{array}$ & Day 128 & 5 months & 5,5 months & 8 months & 12 months \\
\hline $\begin{array}{l}\text { Thelarche } \\
\text { (Tanner stage) }\end{array}$ & & 2 & 2 & 2 & 2 & 2 & 2 \\
\hline $\begin{array}{l}\text { АСТН } \\
(1-46 \mathrm{pg} / \mathrm{ml})\end{array}$ & 36 & 24 & & & & & \\
\hline $\begin{array}{l}17 \mathrm{OHP} \\
(0.53-1.86 \mathrm{ng} / \mathrm{ml})\end{array}$ & 2.5 & 1.84 & & & & & \\
\hline $\begin{array}{l}\text { DHEA-S } \\
(1-45 \mu \mathrm{g} / \mathrm{dl}))\end{array}$ & & 1393 & 1008 & 218 & & & \\
\hline $\begin{array}{l}1-4 \Delta \mathrm{AS} \\
(0.18-0.80 \mathrm{ng} / \mathrm{ml})\end{array}$ & & 1.8 & & & & & \\
\hline $\begin{array}{l}\text { T.T } \\
(0-40 \mathrm{ng} / \mathrm{dl})\end{array}$ & 66 & 89 & 22 & & & & \\
\hline $\begin{array}{l}\mathrm{LH} \\
(0.02-7.0 \mathrm{mIU} / \mathrm{l})\end{array}$ & 15 & 22.5 & 20.6 & 2.82 & 4.2 & $<0.7$ & $<0.7$ \\
\hline $\begin{array}{l}\text { FSH } \\
(0.24-14.2 \mathrm{mIU} / \mathrm{l})\end{array}$ & 20 & 15.7 & 8.9 & 5.8 & 7.2 & 5.6 & 4.8 \\
\hline $\begin{array}{l}\mathrm{E}_{2} \\
(0-36 \mathrm{pg} / \mathrm{ml}) \\
\text { Pelvis USG }\end{array}$ & 497 & 447 & $>1000$ & $>1000$ & 160 & 34 & $<12$ \\
\hline $\begin{array}{l}\text { Uterine size } \\
\text { Endometrial } \\
\text { thickness (mm) }\end{array}$ & & $35 \times 12 \times 14$ & $36 \times 12 \times 15$ & $\begin{array}{c}37 \times 17 \times 15 \\
\text { E: } 3\end{array}$ & $\begin{array}{c}37 \times 15 \times 17 \\
\text { E. } 3\end{array}$ & $\begin{array}{c}33 \times 18 \times 13 \\
\text { E: } 3\end{array}$ & $20 \times 13 \times 10$ \\
\hline $\begin{array}{l}\text { Right ovary size } \\
\text { Cyst size } \\
(\mathrm{mm})\end{array}$ & & $\begin{array}{l}26 \times 14 \times 14 \\
25 \times 14 \times 12\end{array}$ & $\begin{array}{l}29 \times 18 \times 22 \\
27 \times 15 \times 20\end{array}$ & $\begin{array}{l}42 \times 38 \times 25 \\
40 \times 33 \times 24\end{array}$ & $\begin{array}{l}38 \times 23 \times 32 \\
35 \times 23 \times 30\end{array}$ & $\begin{array}{c}23 \times 9 \times 15 \\
\text { multiple cysts } \\
\text { (Largest: } 9 \mathrm{~mm} \text { ) }\end{array}$ & $\begin{array}{l}12 \times 11 \times 8 \\
\text { follicular cyst } \\
(2-3 \mathrm{~mm})\end{array}$ \\
\hline $\begin{array}{l}\text { Left ovary size } \\
\text { Cyst size } \\
(\mathrm{mm})\end{array}$ & & $\begin{array}{c}10 \times 8 \times 6 \\
-\end{array}$ & $\begin{array}{l}\text { 17x11x10 } \\
\text { follicular cyst } \\
\qquad(2 \mathrm{~mm})\end{array}$ & $\begin{array}{l}\text { 19x9x11 } \\
\text { follicular cyst } \\
\qquad(2 \mathrm{~mm})\end{array}$ & $\begin{array}{c}20 \times 8 \times 11 \\
-\end{array}$ & $\begin{array}{c}18 \times 15 \times 13 \\
-\end{array}$ & $\begin{array}{c}17 \times 11 \times 9 \\
-\end{array}$ \\
\hline Echocardiography & & & & $\begin{array}{c}4 \mathrm{~mm} \\
\text { pericardial } \\
\text { effusion }\end{array}$ & & & Normal \\
\hline Bone age & & & & & & & $\begin{array}{l}1 \text { year } 3 \\
\text { months }\end{array}$ \\
\hline
\end{tabular}

ACTH: adrenocorticotrophic hormone, 17OHP: 17OH-Progesterone,

DHEA-S: dehydroepiandrosterone sulphate, AS: androstenedione, T.T: total testosterone,

LH: luteinizing hormone, FSH: follicle stimulating hormone, $\mathrm{E}_{2}$ : Estradiol, E: Endometrial thickness

were reported in 21 POHS in spite of very high $\mathrm{E}_{2^{\prime}}$ except 5 cases of stage 2 thelarche and one case of vaginal bleeding. ${ }^{15,16}$ This is explained by decreased sensitivity of peripheral $\mathrm{E}_{2}$ receptors as a result of immature gonadal axis. ${ }^{5,15,16}$ In our case, stage 2 thelarche, increased size of uterus and increased endometrium thickness were detected. These different clinical presentations support the idea that sensitivity of peripheral $\mathrm{E}_{2}$ receptors can vary among people. 
Clitoris edema in POHS, as in our case can give an image of ambiguous genitalia. Patients with clitoromegaly who are $46, \mathrm{XX}$ must be evaluated for congenital adrenal hyperplasia. Ovarian cysts are a presentation common to both congenital adrenal hyperplasia and POHS. ${ }^{17}$ Normal levels of 17OHP, preterm birth and long term follow up in NICU were factors for ruling out congenital adrenal hyperplasia and a faster conclusion to the diagnosis of POHS.

The treatment of POHS is conservative with close follow up if there is no rupture of ovarian cyst or risk of torsion. ${ }^{1}$ In our search of the literature, we found the majority (21) of cases to have resolved spontaneously, other than 4 complicated cases (2 treated with medroxyprogesterone acetate, 1 surgery, 1 surgery + medroxyprogesterone acetate). Our patient was seen in frequent outpatient visits for rupture of ovarian cyst or torsion. Laboratory results and clinical signs were completely normal on 8 months of postnatal age.

In conclusion; POHS should be considered in the differential diagnosis in preterm babies referred for clitoromegaly after congenital adrenal hyperplasia is ruled out. In spite of severe clinical signs, these symptoms resolve spontaneously without treatment as seen in our patient. Although pericardial effusion is seen in adult OHSS, it is the first case defined in POHS. Therefore, the patients should be seen frequently for rupture of ovarian cyst or torsion or other complications such as pericardial/ pleural effusions. Advanced research can enlighten the exact pathogenesis of the disease.

\section{REFERENCES}

1. Starzyk J, Wójcik M, Wojtyś J, Tomasik P, Mitkowska Z, Pietrzyk JJ. Ovarian hyperstimulation syndrome in newborns--a case presentation and literature review. Horm Res 2009; 71: 60-64.

2. Mondal R, Chatterjee K, Samanta M, et al. Clitoral length and anogenital ratio in Indian newborn girls. Indian Pediatr 2016; 53: 299-303.
3. Forest MG, De Peretti E, Bertrand J. Hypothalamicpituitary-gonadal relationships in man from birth to puberty. Clin Endocrinol (Oxf) 1976; 5: 551-569.

4. Acherman JC. Endocrinology of newborn. In: Brook CGD, Clayton P, Brown R (eds). Brook's Clinical Pediatric Endocrinology (5th ed). Development of the Reproductive Systems (Chapter 8). Oxford: Blackwell, 2005; 153-170 .

5. Greaves RF, Hunt RW, Chiriano AS, Zacharin MR. Luteinizing hormone and follicle-stimulating hormone levels in extreme prematurity: development of reference intervals. Pediatrics 2008; 121: e574-e580.

6. Halis H, Memur S, Korkmaz L, Baştuğ O, Güneş T, Kurtoğlu S. Ovarian hyperstimulation syndrome treated by medroxyprogesterone acetate. J Pediatr Endocrinol Metab 2014; 27: 997-999.

7. Elchalal U, Schenker JG. The pathophysiology of ovarian hyperstimulation syndrome--views and ideas. Hum Reprod 1997; 12: 1129-1137.

8. Irani M, Robles A, Gunnala V, Chung P, Rosenwaks Z. Unilateral pleural effusion as the sole clinical presentation of severe ovarian hyperstimulation syndrome: a systematic review. Gynecol Endocrinol 2018; 34: 92-99.

9. Delvigne A, Demoulin A, Smitz J, et al. The ovarian hyperstimulation syndrome in in-vitro fertilization: a Belgian multicentric study. I. Clinical and biological features. Hum Reprod 1993; 8: 1353-1360.

10. Delbaere A, Bergmann PJ, Gervy-Decoster C, Camus M, de Maertelaer V, Englert Y. Prorenin and active renin concentrations in plasma and ascites during severe ovarian hyperstimulation syndrome. Hum Reprod 1997; 12: 236-240.

11. McClure N, Healy DL, Rogers PA, et al. Vascular endothelial growth factor as capillary permeability agent in ovarian hyperstimulation syndrome. Lancet 1994; 344: 235-236.

12. Loret de Mola JR, Arredondo-Soberon F, Randle $\mathrm{CP}$, Tureck RT, Friedlander MA. Markedly elevated cytokines in pleural effusion during the ovarian hyperstimulation syndrome: transudate or ascites? Fertil Steril 1997; 67: 780-782.

13. Balasch J, Reverter JC, Fabregues F, Tassies D, Ordinas A, Vanrell JA. Increased induced monocyte tissue factor expression by plasma from patients with severe ovarian hyperstimulation syndrome. Fertil Steril 1996; 66: 608-613.

14. Schenker JG. Prevention and treatment of ovarian hyperstimulation. Hum Reprod 1993; 8: 653-659. 
15. Altuntas N, Turkyilmaz C, Yuce O, et al. Preterm ovarian hyperstimulation syndrome presented with vaginal bleeding: a case report. J Pediatr Endocrinol Metab 2014; 27: 355-358.

16. Sun $Y$, Chen C, Di T, et al. Clinical characteristics of preterm ovarian hyperstimulation syndrome: seven cases from China and 14 cases from the literature. Gynecol Endocrinol 2019; 35: 819-824.
17. Şahin NM, Bayramoğlu E, Çetinkaya S, et al. Vaginal bleeding and a giant ovarian cyst in an infant with 21-hydroxylase deficiency. J Pediatr Endocrinol Metab 2018; 31: 229-233. 